\title{
Development of Psychic Pain in the Context of Microcephaly and Abortion: Systematic Review and Meta-Analysis
}

\author{
Uilna Natércia Soares Feitosa1, Danilo Ferreira de Sousa², \\ Poliana Moreira de Medeiros Carvalho, 1,2,3, Raquel Guimarães Kanda ${ }^{4}$, Joaquim Alves Diniz ${ }^{3}$, \\ Luis Clescivan Ferreira Nobre ${ }^{3}$, Dayse Christina Rodrigues Pereira Luz ${ }^{1,2}$, \\ Wilma José Santana ${ }^{25}$, Cícera Jaqueline Sobreira Andriola1, Nélio Barreto Vieira4, \\ Antonio Souto Gouveia1, Alberto Olavo Advincula Reis ${ }^{5}$, \\ Caio Parente Barbosa1, Modesto Leite Rolim Neto ${ }^{1,3,4}$ \\ ${ }^{1}$ Programa de Pós-Graduação em Ciências da Saúde, Faculdade de Medicina do ABC-FMABC, Santo André, São Paulo, Brazil \\ ${ }^{2}$ Faculdade de Juazeiro do Norte, FJN, Juazeiro do Norte, Ceará, Brazil \\ ${ }^{3}$ Faculdade de Medicina, Estácio/FMJ, Juazeiro do Norte, Ceará, Brazil \\ ${ }^{4}$ Faculdade de Medicina, Universidade Federal do Cariri-UFCA, Barbalha, Ceará, Brazil \\ ${ }^{5}$ Programa de Pós-Graduação em Saúde Pública, Universidade de São Paulo-USP, São Paulo, Brazil \\ Email: modestorolim@yahoo.com.br
}

How to cite this paper: Feitosa, U.N.S., de Sousa, D.F., de Medeiros Carvalho, P.M., Kanda, R.G., Diniz, J.A., Nobre, L.C.F., Luz, D.C.R.P., Santana, W.J., Andriola, C.J.S., Vieira, N.B., Gouveia, A.S., Reis, A.O.A., Barbosa, C.P. and Neto, M.L.R. (2017) Development of Psychic Pain in the Context of Microcephaly and Abortion: Systematic Review and Meta-Analysis. Health, 9, 376391.

https://doi.org/10.4236/health.2017.92026

Received: November 22, 2016

Accepted: February 20, 2017

Published: February 23, 2017

Copyright $\odot 2017$ by authors and Scientific Research Publishing Inc. This work is licensed under the Creative Commons Attribution International License (CC BY 4.0).

http://creativecommons.org/licenses/by/4.0/ (c) (i) Open Access

\begin{abstract}
Background: In the year of 2015, evidence of a relation between Zika virus and the development of microcephaly in pregnant women who acquired the infection started to come up. Thus, it is extremely necessary that the analysis of the affliction affects these women in a biopsychosocial context, in order to discuss and comprehend in a more reliable manner the affection from the perception of the disease, origin, and psychic pain mechanisms. Methods: Systematic review with meta-analysis, using the PRISMA protocol. The study period was 2016 and the keywords included "microcephaly" and "abortion", one at a time and then combined with the Boolean operator "AND." The statistical analysis was done using the BioEstat 5.0 program. Calculation was based on an adjustment of Mantel-Haenszel random effect. Results: 41,046 registrations were found. Of this total, 40,992 articles were excluded because they only mentioned the fact or referred to spontaneous abortion, did not analyze abortion on the eyes of microcephaly, only treated with Zika virus, or were repeated. Limitations: Psychic pain and suffering need studies in the mother/son/disease relation, which were not found in the databases. The article was based on other sources. Conclusions: The pains vary in different areas of the female life, since internal conflicts, gender violence, stress, fear, insecurity, psychologic torture, grieve, loneliness, among other kinds of psychic suffering. More studies on psycho-emotional themes need to be pro-
\end{abstract}


moted to discuss the female suffering on a wider vision, closer to the reality faced by these women.

\section{Keywords}

Abortion, Microcephaly, Psychic Pain

\section{Introduction}

In the beginning of 2015, an outbreak of Zika virus, which is transmitted through Aedes aegypti mosquito, was identified in Northeastern Brazil, mainly around Pernambuco, where the epidemic was increasing [1]. Hence, based on the $86 \%$ amount of children born with microcephaly, especially in the northeastern part of the country [2], evidence started to come up about a relation between Zika virus and the development of microcephaly in infected pregnant women. On the one hand, Zika virus is responsible for the increase of microcephaly cases in Brazil; on the other hand, one of the most conservative political panoramas of the last years stands out, the legal abortion. In the midst of this, there is a public health emergency, in which pregnant women's physical and mental health is at stake [3]. Therefore, it is extremely necessary that the analysis of the affliction affects these women in a biopsychosocial context in order to discuss and comprehend in a more reliable manner the affection from the perception of disease, nature, and psychic pain mechanisms.

In fact, compulsory pregnancy in the context of Zika virus epidemic has opened space for mental health discussions. Firstly, it is due to the fact that women are undergoing psychological torture, and consequently producing potential damage to their physical, psychological, and social health. Secondly, due to the lack of social policies aimed at maternity and childhood, so they are submitted to abandonment and violation of their essential rights. This is the cruel face of the outbreak on women, which cannot be forgotten [4].

Thus, at short-term, the virus is becoming a source of concern for the entire planet and now is the focus of attention of the World Health Organization (WHO). In a global panorama, we need to be calm so we do not succumb to fear of the virus [5].

For the parents, having a child with microcephaly may mean a life full of uncertainties. Diagnosis is normally possible during the half part of the gestational period. It is not possible to affirm how the future of every child with microcephaly will be [6]. We also need to emphasize that most infected women are poor and live under unhealthy conditions, are not sexually educated, nor have access to contraceptives. These women cannot decide when they will have sexual intercourses, nor have the right of a worthy life [7]. The daily routine of pregnant women is always similar: living each day with apprehension, insecurity, and few pieces of information. The latter point is the most sensitive [1]. In this condition, a woman faces a psychic pain due to the possibility of loss, in which the maternal 
protection instinct reaches its highest level and brings a reaction to the representation of losing an object through circumstances that develop desire's dissatisfaction, which are surrounded by periods of intense anxiety. Uncertainty of a child's future inserts the extreme psychic pain state, in which the pregnant woman infected with Zika is destabilized abruptly and painfully.

Besides these factors, there is also the abandonment situation, whether by the partners or by the lack of public policies of support, which makes the woman feel an extreme psychic and social pain. Double abandonment is a woman who does not receive protection from social policies, since there are no health policies nor social assistance aimed at the epidemic effects, besides partner's abandonment; she lives maternity facing an experience of total loneliness and neglect. Abandonment of men reflects an unfair gender regimen to women, and the State's neglect is a violation of these women's main rights. Thus, it is a double abandonment" [2].

In this way, the Brazilian scenario has an eminent reality in which the population is at risk, pregnant women are facing vulnerability, because even in an epidemic situation, they do not have the right of getting an abortion in the event of microcephaly diagnosis. In this situation, the United Nations (UN) have raised discussions about the guarantee of access to contraceptive methods and abortion for women diagnosed with microcephaly fetuses, mainly in Latin America countries, where most of the cases were registered and where there are very strict laws regarding abortion [8].

Thus, the central panorama in the discussion of abortion in the event of microcephaly is not the possible malformation, but the epidemic. Regardless of the concrete effects the infection might cause in the fetus, the epidemic itself has severe effects on women. Making a woman face the outbreak uncertainty is a torture $[\ldots]$ These women's dramatic reality requires immediate actions to guarantee their rights [4].

It is not the abortion itself that is being discussed recently, but the rights of women as to decide in continuing or interrupting pregnancy after microcephaly diagnosis [9]. In Brazil, abortion is only allowed in cases of pregnancy from a violation, risk of death for the pregnant woman and fetus anencephaly. In the last case, the Supreme Federal Court opened the possibility in 2012, because such situation is not compatible with life. The thesis that there would not be a life to protect prevailed, therefore obligating a woman to continue the pregnancy, which would result in a death being in the end, is an offense to her dignity and an act of torture [10]. A judge in Brasília, Brazil, has taken the rare step of publicly proclaiming that he will allow women to promote legal abortions in cases of microcephaly, by making way for a fight over the issue in parts of the country with a complex legal system [9].

Another theme that severely affects pregnant women infected with Zika is the religious conflict. Most Latin American countries are catholic [11]. In February, the Catholic Church in Brazil-one of the countries most affected by the virusstated that it is strongly opposed to allowing abortions of pregnant women ex- 
posed to the virus. "There is no justification to defend abortion"-the Church declared [12]. Cardinal Oscar Rodriguez Maradiaga from Honduras, one of the main advisors of Pope Francisco, accused the idea of "therapeutic abortion"-due to fetal abnormalities-as a response to birth defects caused by the Zika virus mosquito, which has been raising awareness in the entire Latin America. "There is no such thing as therapeutic abortion," he said. "Therapeutic means cure, and abortion does not heal anything. Innocent lives are necessary" [13]. "The Guardian" declares the need of promoting women's vision in these countries, who need calmness and help as soon as possible. Since danger is seen in the conception, relief should be located in the access to contraceptives and in the guarantee of reproductive rights. It is not a judgment of principles or religiosity, but the feeling of being the mother of a possible incapable being [9].

Discussion at global level involving the development of psychic pain in pregnant women associated with the risk of microcephaly in the fetus is still rare, although it is commonly carried out. Showing these manifestations is extremely important in the clinical practice, because a significant damage to health, especially mental health, can be caused to women.

\section{Methods}

This is a systematic review with meta-analysis using the PRISMA protocol (http://www.prisma-statement.org/) to prepare the review and the meta-analysis. During study search, some steps were adopted, such as the research line and eligibility of articles, analysis of the findings to establish which articles would be included, and data interpretation based on the study orientation.

The guiding question followed the PICO acronym, in which $\mathrm{P}$ is the pregnant woman; I is the risk of being born with microcephaly; C-newspapers of great distribution; and $\mathrm{O}$ are the types of psychic pain. The guiding question was punctuated on the repercussion in newspapers of great distribution internationally and nationally about psychic pain in pregnant women at risk of the child being born with microcephaly. The newspapers in Figure 1 were used for data research.

Interviews and reports about the subject, related to the year of 2016, were included, with registrations found in English, Spanish and Portuguese that approached abortion, microcephaly, and/or psychic pain. The study period was chosen because the knowledge production is recent, thus it restricted registration from previous years.

Studies referring to spontaneous abortion that did not show a clear positioning on abortion and/or psychic pain, repeated registrations or that analyzed the causes of microcephaly only were excluded. "Microcephaly" and "abortion" were the keywords used separately and later combined with the Boolean operator “AND".

$$
\begin{aligned}
& \text { \#1. "Microcephaly" and } \\
& \text { \#2. "Abortion" } \\
& \# 1 \text { and \#2 }
\end{aligned}
$$




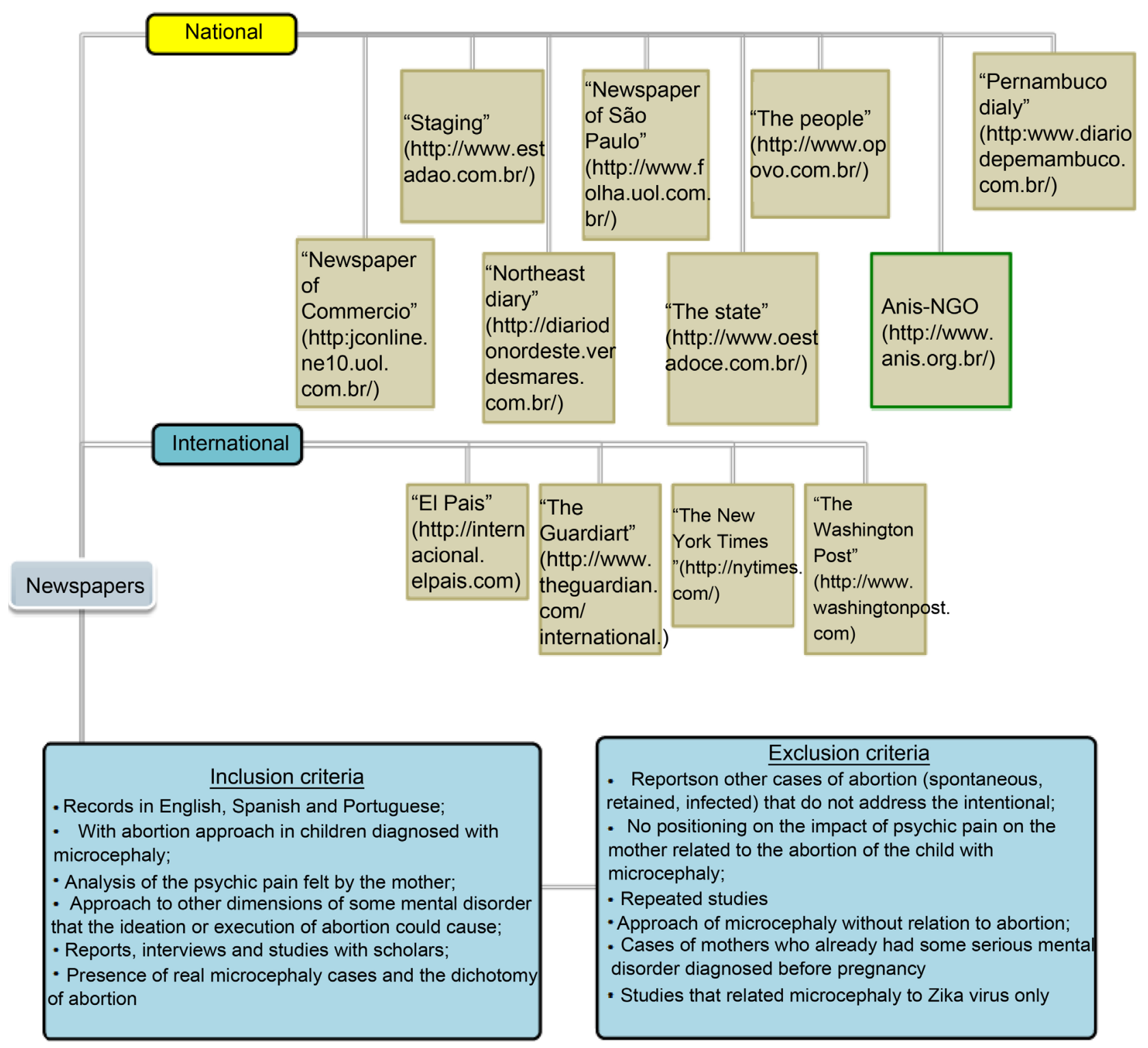

Figure 1. Newspapers used for the search. Source: Developed by the authors.

The databases used were The People, The State, Newspaper of Commercio, Northeast Journal, Pernambuco Daily, Stating, Newspaper of São Paulo, El País, The New York Times, The Washington Post, The Guardian and Anis. The keywords "microcephaly" and "abortion" were entered with the AND operator in the search box of each source and the period between 01/01/2016 and 07/ 30/2016 was selected. The selection process was the same for all databases.

During the process of study selection, two reviewers worked independently and analyzed the studies that would be included. In case of disagreement, a third reviewer was used for the verdict on the inclusion or non-inclusion of the study.

The statistical analysis used the BioEstat 5.0 program. Measurement followed a calculation adjustment of Mantel-Haenszel random effect to analyze an association between microcephaly, possible induced abortion, and development of some impact on female mental health. 


\section{Results}

A total of 41,046 registrations were found, i.e. 466 were The People; 56, The State; 8344, Jornal do Commercio; 266, Diário do Nordeste; 31,244, Diário de Pernambuco; 64, Estadão; 408, Folha de São Paulo; 45, El País; 40, The New York Times; 50, The Washington Post; 50, The Guardian; 13, Anis. Of this amount, 40,992 articles were excluded because they only mentioned or referred to spontaneous abortion, did not analyze abortion on the vision of microcephaly, approached only Zika virus, or were repeated. Figure 2 summarizes the methodological process of article selection.
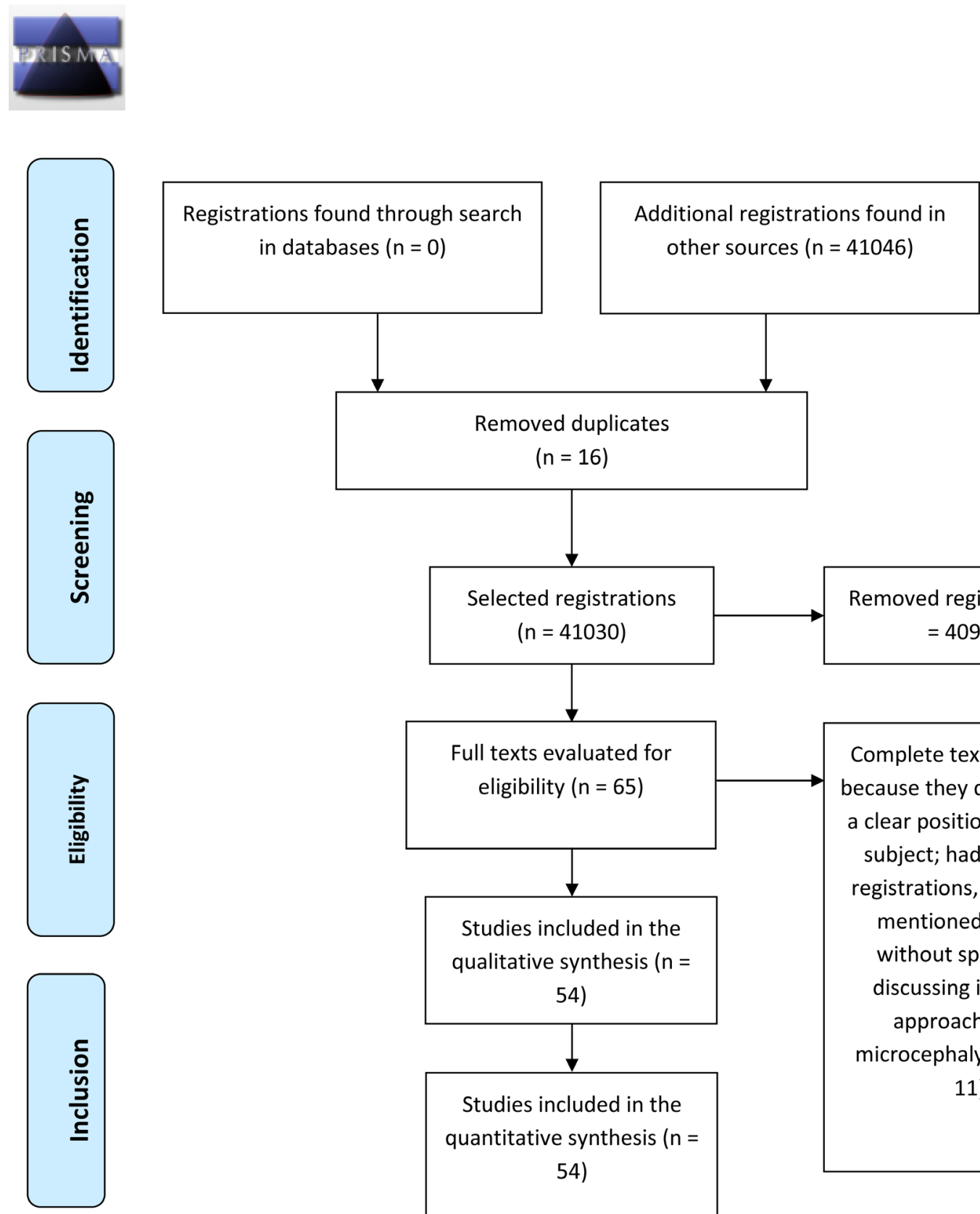
other sources ( $n=41046)$
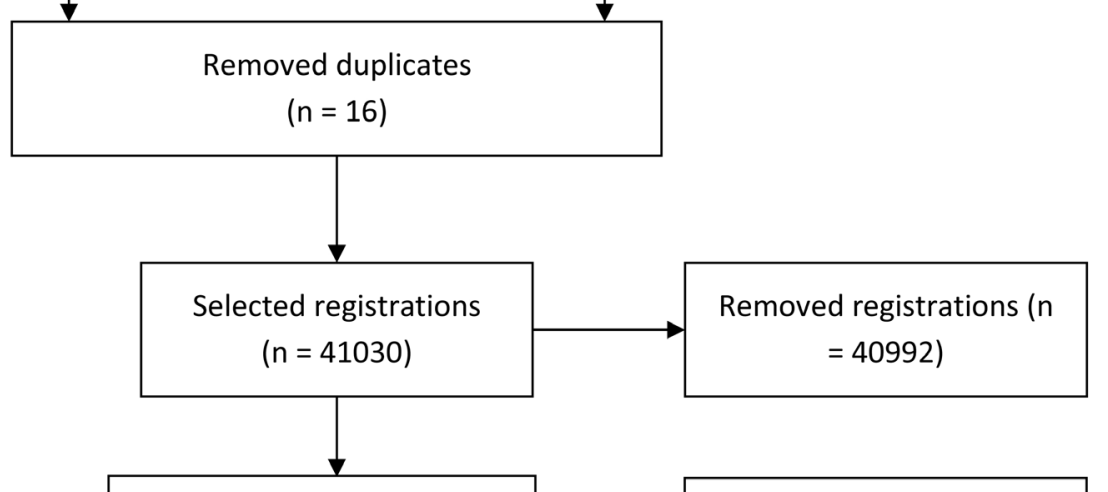

Full texts evaluated for eligibility $(n=65)$

Complete texts removed because they did not show a clear positioning on the subject; had repeated registrations, which only mentioned the fact without specifically discussing it; or that approached the microcephaly cases $(n=$

Studies included in the 11)

Figure 2. Flowchart of study search. Source: Developed by the authors. 
Chart 1 includes a global summary of the findings in the investigated newspapers.

Ideation or need of a possible abortion may create a psychic pain in women, which can be manifested in several ways and negatively affect their mental health. Figure 3 includes the statistical analysis regarding the chances of developing psychic pain; Figure 4 and Figure 5 show the amount of included registrations and those punctuating mental health; and Figure 6 shows the main kinds of psychic pain found in international and national newspapers.

A total of 123 cases were analyzed. Mantel-Haenszel test and Odds Ratio measured the association between the possible risk of microcephaly development associated with abortion ideation and development of some psychic pain in women. Each group of studies is represented with a line. The square represents the effect of studies and the line represents the confidence interval. The size of squares represents the weight of each group of studies for the statistical analysis. The vertical line indicates absence of effect, and the diamond symbolizes the result of the meta-analysis.

A woman with a fetus that is at risk of developing microcephaly and has a perspective of abortion would have, based on the statistical analysis, four more

Chart 1. Main findings [1]-[54].

\begin{tabular}{|c|c|}
\hline Newspaper & Main approach \\
\hline The Guardian & Approach focused on clandestine abortion. \\
\hline The New York Times & $\begin{array}{l}\text { Risk of American women being infected with Zika virus when } \\
\text { traveling to tropical countries. }\end{array}$ \\
\hline The Washington Post & $\begin{array}{c}\text { Analysis of the action mechanism of Zika virus in the central } \\
\text { nervous system (CNS), and the issue regarding contraceptive and } \\
\text { abortion in Latin America. }\end{array}$ \\
\hline El País & $\begin{array}{l}\text { It presents a more humanized vision of the Zika-Microcephaly } \\
\text { issue, focusing on the difficulties that the Latin woman faces with } \\
\text { the problem, socioeconomically and religiously. }\end{array}$ \\
\hline The peaple & $\begin{array}{l}\text { It discusses the limitation of knowledge regarding the subject to } \\
\text { allow the legalization of abortion. }\end{array}$ \\
\hline The state & Abortion is not the answer. \\
\hline Newspaper of Commercio & $\begin{array}{l}\text { It associates the abortion issue with a strong influence of } \\
\text { eugenic ideas, as well as the fact that legislation does } \\
\text { not support the issue. }\end{array}$ \\
\hline Northeast diary & $\begin{array}{c}\text { It defends prevention against infection through Zika } \\
\text { virus, instead of abortion. }\end{array}$ \\
\hline Pernambuco diary & $\begin{array}{l}\text { It emphatically discusses the rights of women in making } \\
\text { decisions regarding their bodies. }\end{array}$ \\
\hline Newspaper of São Paulo & $\begin{array}{l}\text { Humanist and social analysis of the Zika virus outbreak in } \\
\text { pregnant women. }\end{array}$ \\
\hline Staging & Legal approach-abortion proposition. \\
\hline Anis & $\begin{array}{l}\text { Analysis aimed at women's humanist perception and } \\
\text { approach aimed at legal aspects. }\end{array}$ \\
\hline
\end{tabular}

Source: Developed by the authors. 


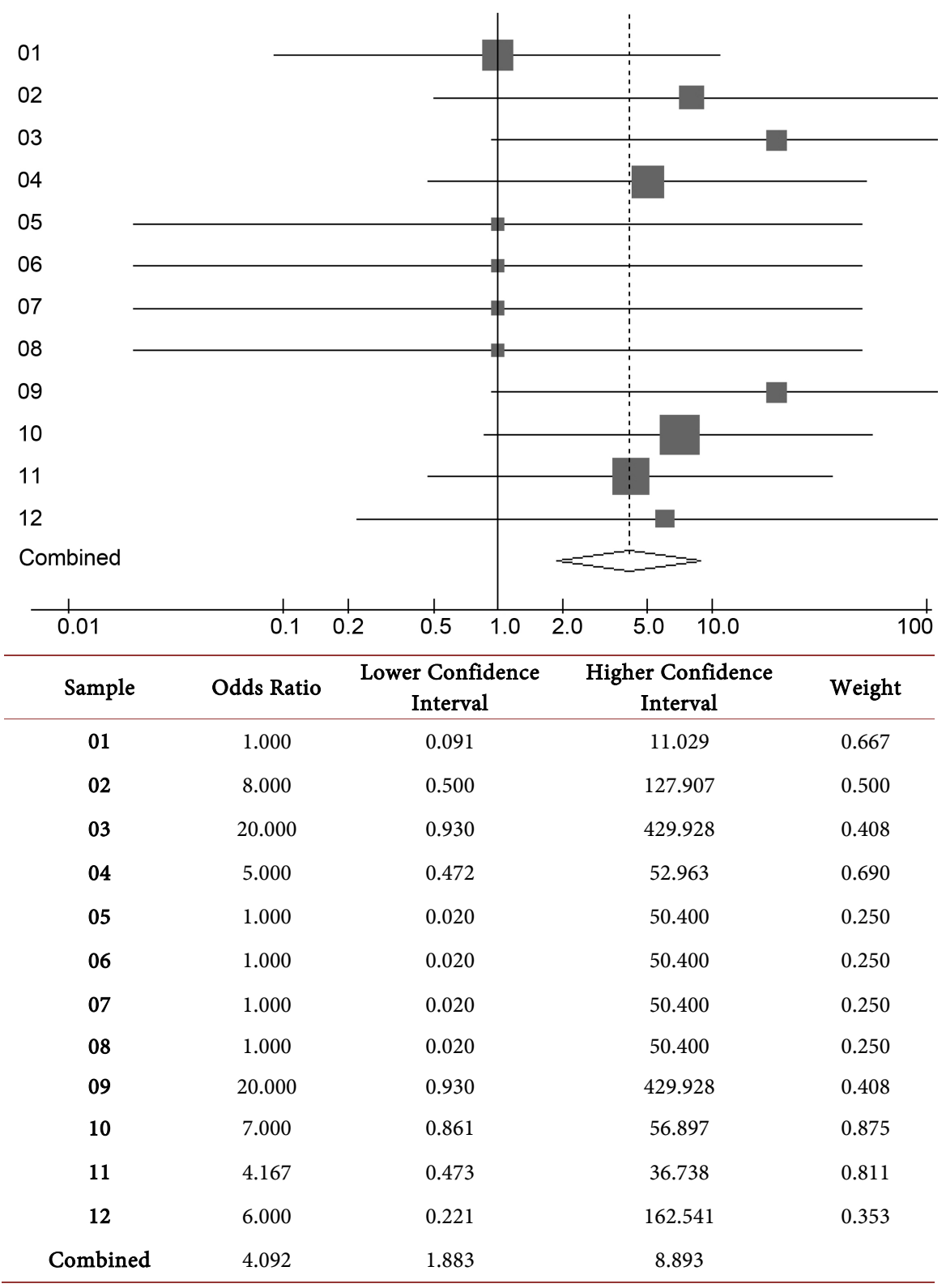

Source: Developed by the authors.

Figure 3. Meta-analysis-statistical association between microcephaly/abortion and the development of psychic pain in women (Mantel-Haenszel and Odds Ratio) [1]-[54].

chances of developing a significant psychic pain of great relevance in the clinical practice.

\section{Discussion}

Based on the analysis of the results, we can infer that psychic pain of pregnant women at risk of microcephaly is in the following spheres: socioeconomic, gender, religious, abortion and internal conflicts.

Violence against women is endemic-in Peru, for example, half of women state that their first sexual intercourse was forced. Poverty remains in the female gender. Access to contraceptives has improved, but it still has low levels for 


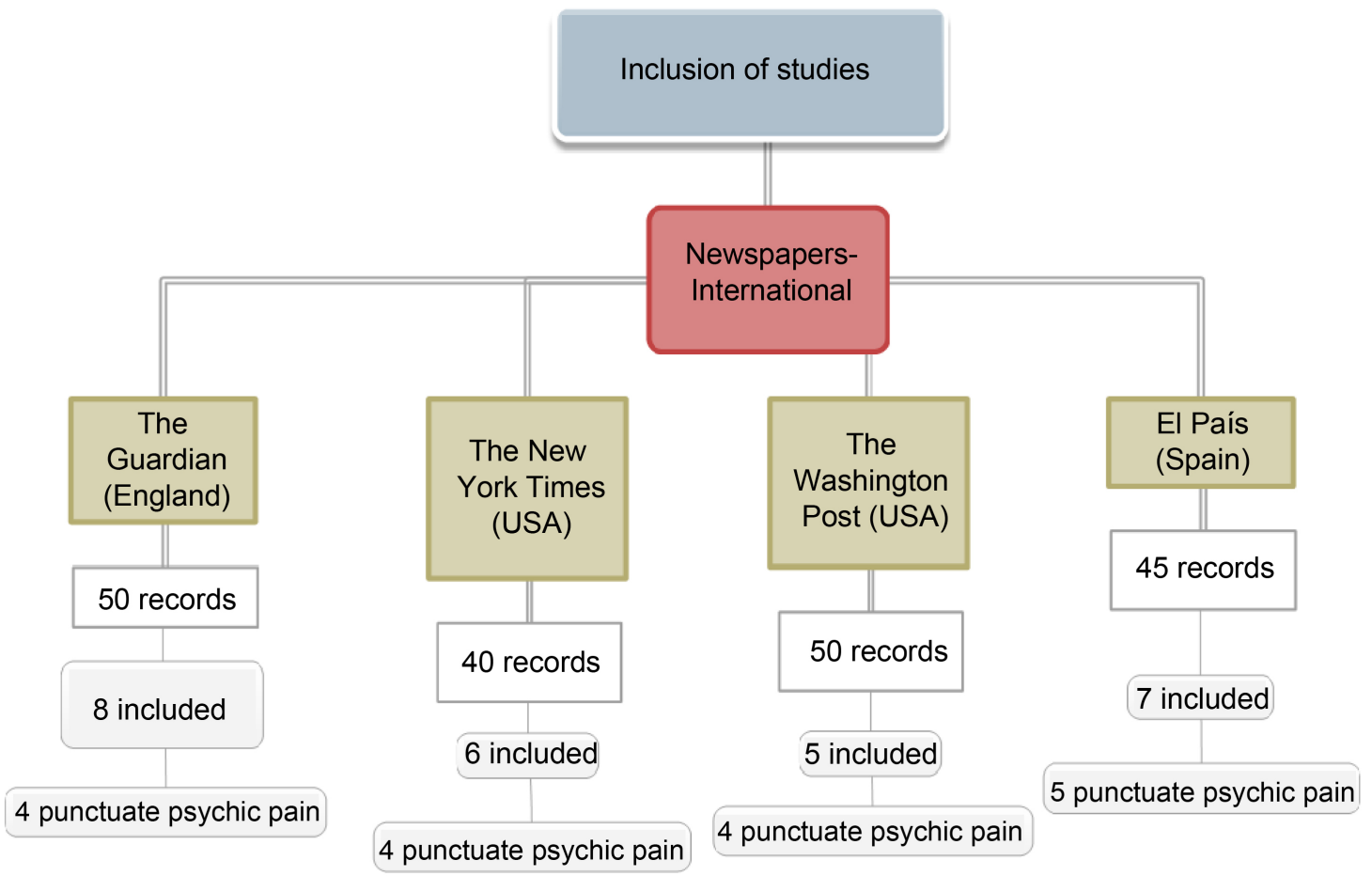

Figure 4. Included registrations and amount of newspapers punctuating mental health-international databases. Source: Developed by the authors.

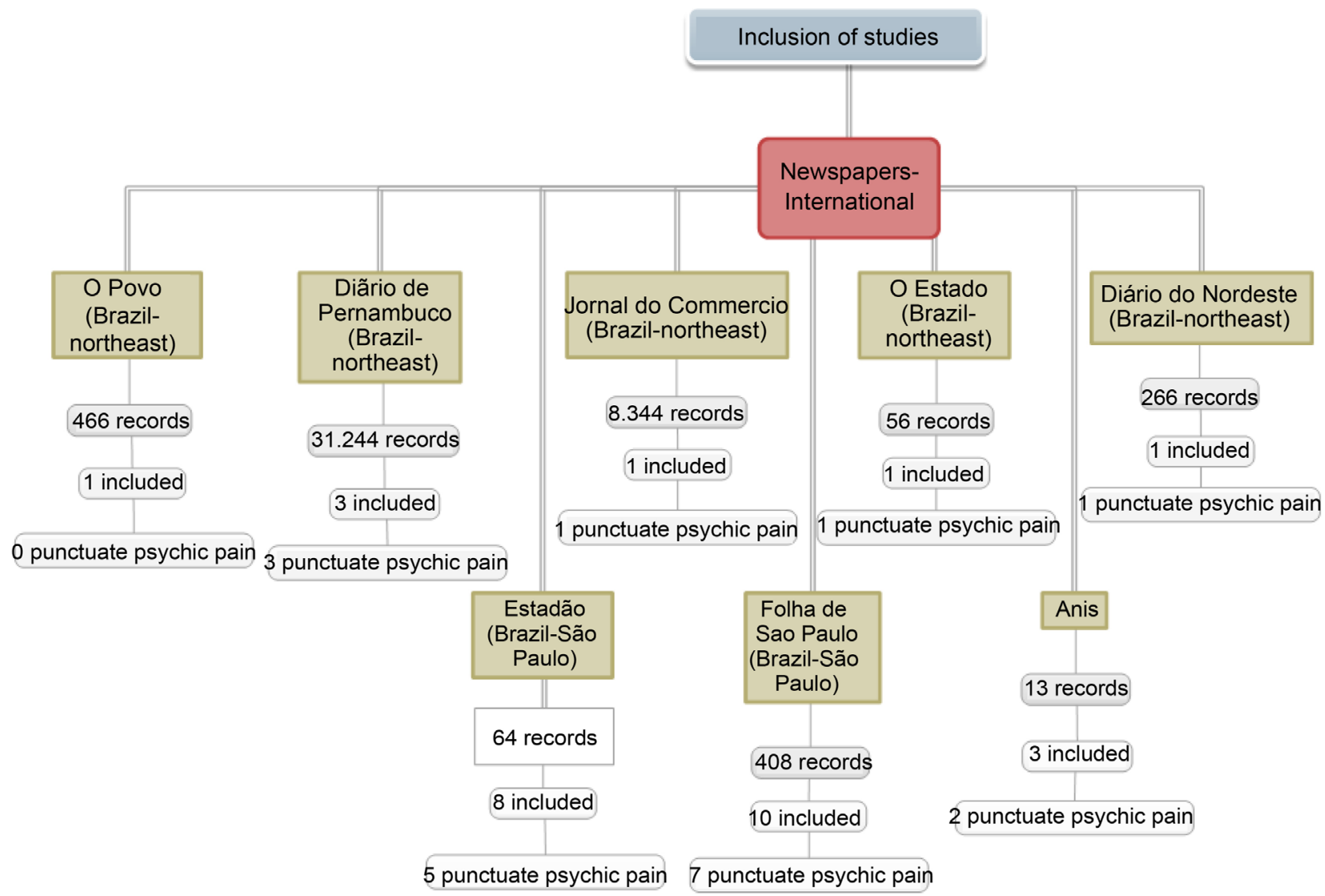

Figure 5. Included registrations and amount of newspapers punctuating mental health-national databases. Source: Developed by the authors. 


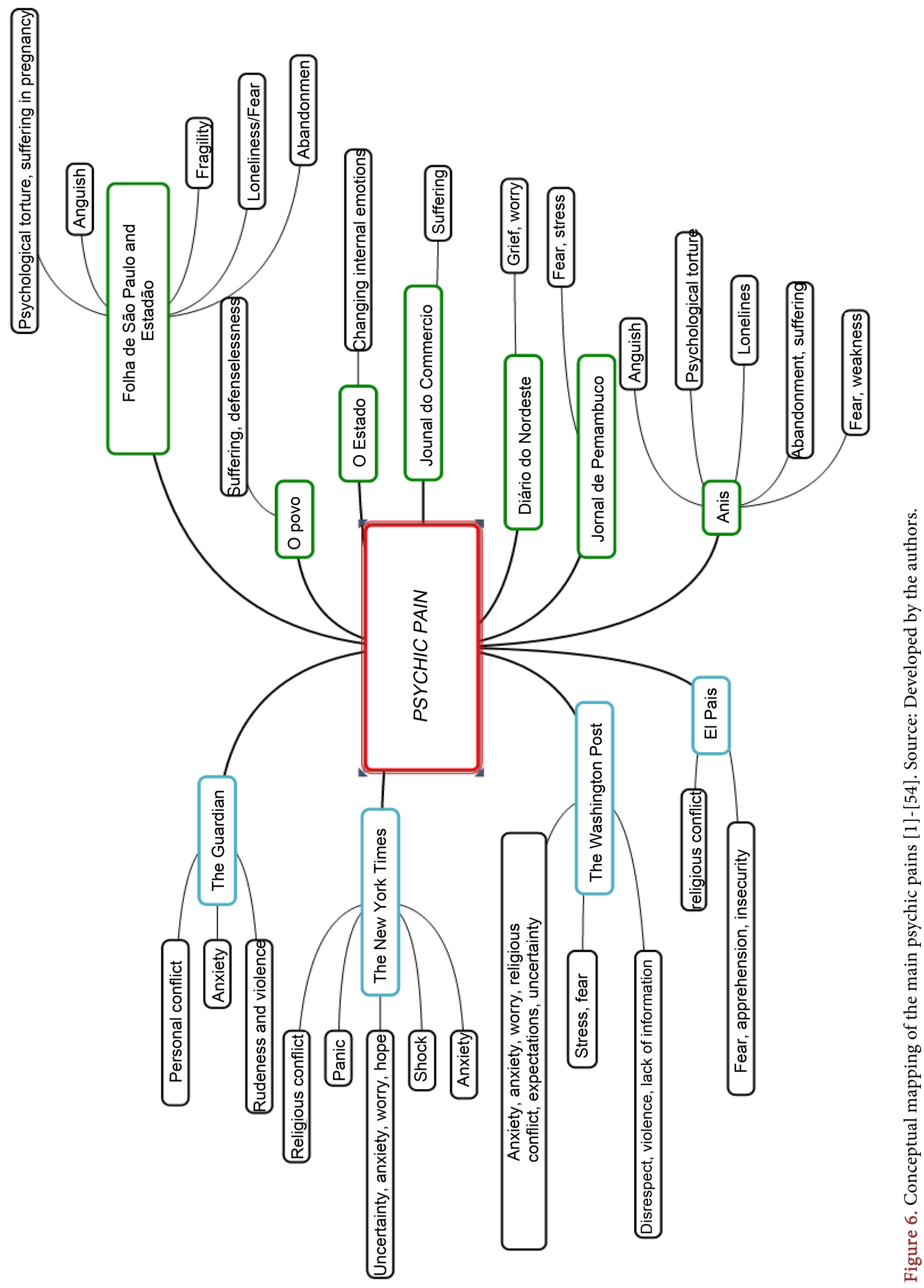

adolescents and women living in low socioeconomic conditions. Health of pregnancies is not planned [14]. "In situations where sexual and reproductive 
health services are penalized, or are simply not available, efforts to stop this crisis do not show a solution, since they focus on the request that women and girls avoid pregnancy," as pointed out in "El País" [8]. A dialogue with citizens about the reason this gender equality and sexual and reproductive rights scenario is happening should also begin. Latin America shows particularities regarding these themes. In a context of extreme inequality, where people with a higher socioeconomic level are at one side, and an extremely poor population is on the other, differences, sexism, violence and lack of control that women have over their own life projects still prevail, although there is already a legislation safeguarding these situations. This discussion is based on another domain: the religions [15].

Many times, religions insert principles that, in many cases, restrict the right of female populations of sparing negative feelings, even when facing circumstances that were approved by science. These facts control a woman's decision power, who subjects herself to the existing principles [16].

Firstly, Latin America, in which most of its population is catholic, faces a delicate religious conflict. Pregnant women exposed to Zika virus that may be carrying fetuses with serious brain defects are not allowed to have an abortion, based on the Vatican's vision. The Catholic Church emphasizes its opposition to abortion under any circumstances, whereas women in Latin America are desperately trying to terminate their pregnancies due to fear of giving birth to babies with microcephaly [12]. "Pregnant women all over Brazil are in panic," said Silvia Camurça, the director of SOS Corpo, which is a feminist group in Recife, Brazil. Fear of Zika virus provides us a rare opening to defy the religious fundamentalism that puts the life of thousands of women at risk ever year in Brazil to maintain its laws and behaviors from the Medieval Age [17]. "The New York Times" highlights that it is a difficult subject, because it is new, requires a complex debate, and most of the religious influence still exists [17].

Abortion is a polemic issue faced by women and can involve the organism in four different plans: body pain associated with the physiological aspect is caused by an injury, while the psychic impact reflects on the sensitivity related to the affectivity for what was lost, an imaginary associated with positive or negative ideations regarding pregnancy and symbolism that such event brings to women's perception. Thus, there could be an unconscious pain, but with great general repercussions on health.

In the midst of this series of moral and social conflicts, women found themselves facing the biggest and most intimate pain: psychic pain of her internal conflicts. The pain caused by Zika virus is quickly overcome; however, the real pain is in the moment when the woman is strong enough to begin worrying about the consequences of the virus to her baby. "It is a moment of loneliness," says a pregnant woman. "Being pregnant with Zika is not something that you can talk to your mother, since it is a new subject. I can hardly wait to have my baby on my arms and see with my own eyes that he is fine" [18]. Fear, uncertainty, and anxiety are inevitable feelings that accompany pregnant women in 
their nine months of pregnancy. The families have a short period to study the subject, receive the results, process their feelings, and make a decision, as stated by "The New York Times" [6].

\section{Conclusions}

Strong evidence points out to the risk of microcephaly development and Zika virus in pregnant women. This proof is an important source of anxiety, expectation, and anguish for all women in the fertile age period. In the midst of this epidemic situation, psychic pain created in the female imaginary takes a large worldwide proportion, and is emphasized in renowned newspapers of large distribution both in Brazil and abroad. The pains showed in each text vary in different ranges of the female life, since internal conflicts, gender violence, stress, fear, insecurity, psychological torture, grieve, loneliness, to other kinds of psychic suffering.

The repercussions of psychic pain for these women refer to particular reactions to the possibilities of lost. Abortion appears as a defensive and protective reaction. Hence, several reflections are expressed in newspapers with the aim of considering the circumstances that develop desire strength, as an external or internal instance of the disease's limit of management.

The woman's pain in this important public health issue should be investigated more carefully. Larger studies on psycho-emotional terms need to be promoted in order to approach the female suffering under a wider vision that is closer to the reality faced by these women. By doing so, it will be possible to provide support to women, not only based on a biological risk, but considering her social, psychological, and emotional plans.

\section{Funding}

This research did not receive any specific grant from funding agencies in the public, commercial, or not-for-profit sectors.

\section{References}

[1] Diniz, D. (2016) Durante crises políticas é muito fácil se fazer concessões a forças conservadoras (Entrevista). El País. http://brasil.elpais.com/brasil/2016/03/08/politica/1457400683 667783.html

[2] Diniz, D. (2016) Para pesquisadora, questão central do aborto não é a microcefalia, mas o direito á saúde da mulher (Entrevista). Jornal do Commercio, Pernambuco. http://m.jc.ne10.uol.com.br/canal/cidades/noticia/2016/02/27/para-pesquisadora-qu estao-central-do-aborto-nao-e-a-microcefalia-mas-o-direito-a-saude-da-mulher-22 3175.php

[3] Oliveira, A. (2016) Las embarazadas brasileñas, entre la expectativa de ser madres y el miedo al vírus del zika. El País, Madrid. http://internacional.elpais.com/internacional/2016/02/03/america/1454516628 288 998.html

[4] Diniz, D. (2016) Casos de microcefalia voltam a colocar o aborto em pauta no Brasil (Opinião). El País. 
http://brasil.elpais.com/brasil/2016/01/29/politica/1454103307 984282.html?id exte rno rsoc $=$ FB $C M$

[5] Diniz, D. (2016) A população de maior risco á epidemia são mulheres pobres e negras do nordeste do país (Entrevista). Fiocruz.

http://www.epsjv.fiocruz.br/noticias/entrevista/a-populacao-de-maior-risco-a-epide mia-sao-mulheres-pobres-e-negras-do-nordeste

[6] Saint-Louis, C. (2016) Microcephaly, Spotlighted by Zika Virus, Has Long Afflicted and Mystified. The New York Times, New York.

http://www.nytimes.com/2016/02/01/health/microcephaly-spotlighted-by-zika-viru s-has-long-afflicted-and-mystified.html

[7] Collucci, C. (2016) Grávidas com Zika fazem aborto sem confirmação de microcefalia. Cotidiano, Folha de São Paulo, São Paulo.

http://www1.folha.uol.com.br/cotidiano/2016/01/1735560-gravidas-com-zika-fazem -aborto-sem-confirmacao-de-microcefalia.shtml

[8] Sahuqullo, M.R. (2016) La ONU insta a garantizar el acesso al aborto en los países afectados por Zika. El País, Madrid.

http://internacional.elpais.com/internacional/2016/02/05/actualidad/1454686710 4 53844.html

[9] McNeil Jr., D.G. (2016) C.D.C. Urges Zika Testing for Some Who Are Pregnant. The New York Times, New York.

http://www.nytimes.com/2016/01/20/health/cdc-urges-zika-testing-for-some-who-a re-pregnant.html? $\mathrm{r}=0$

[10] Brum, E. (2016) Sobre el aborto, la discapacidad y los límites. El País, Madrid. http://internacional.elpais.com/internacional/2016/02/03/actualidad/1454456312 5 98001.html

[11] Lakhani, N. (2016) "Zika-Linked" Miscarriages Pose Jail Risk for Women in El Salvador, Activists Say. The Guardian, London.

http://www.theguardian.com/global-development/2016/feb/12/zika-linked-miscarri ages-pose-jail-risk-women-el-salvador-activists-say

[12] Sherwood, H. (2016) Vatican Says Abortion in "Illegitimate Response" to Zika Vírus. The Guardian, London.

https://www.theguardian.com/world/2016/feb/18/vatican-says-abortion-is-illegitim ate-response-to-zika-virus

[13] Cha, A.E. (2016) Why Zika Is a Ticking "Time Bomb" for Latin America. The Washington Post, Washington.

https://www.washingtonpost.com/news/to-your-health/wp/2016/02/03/a-zika-timebomb-with-limited-access-to-birth-control-and-strict-abortion-laws-women-in-lati n-america-fear-the-future/

[14] Filipovic, J. (2016) Zika Is the Latest Example of How Hard It Is to Be a Woman in Latin America. The Washington Post, Washington.

http://www.washingtonpost.com/posteverything/wp/2016/02/03/zika-is-the-latest-e xample-of-how-hard-it-is-to-be-a-woman-in-latin-americal

[15] Ayuso, S. (2016) Combatir el Zika tratando solo de erradicar al mosquito no funcionará. El País, Madrid.

http://internacional.elpais.com/internacional/2016/02/03/actualidad/1454456312 5 98001.html

[16] Buarque, C. (2016) Você é a favor do aborto em casos de microcefalia? Cristina Buarque afirma que sim. Diário de Pernambuco, Pernambuco.

http://www.diariodepernambuco.com.br/app/noticia/politica/2016/02/14/interna $\mathrm{p}$ olitica,626918/voce-e-a-favor-do-aborto-em-casos-de-microcefalia-cristina-buarque 
-af.shtml

[17] Romero, S. (2016) Surge of Zika Virus Has Brazilians Re-Examining Strict Abortion Laws. The New York Times, New York.

http://www.nytimes.com/2016/02/04/world/americas/zika-virus-brazil-abortion-la ws.html

[18] Fisher, M., Partlow, J. and Jordan, M. (2016) Zika's Terrifying Path. The Washington Post, Washington.

https://www.washingtonpost.com/news/world/wp/2016/03/25/kim-conley-zika-viru s-rio-olympics/

[19] Aguilares, N.L. (2016) El Salvador's Zika Crisis Compounded by Failings of State, Violence and Machismo. The Guardian, London.

http://www.theguardian.com/global-development/2016/feb/12/el-salvador-zika-cris is-compounded-by-failings-of-state-violence-and-machismo

[20] Al-Gailani, S. (2016) From Rubella to Zika: Pregnancy, Disability, Abortion and the Spectre of an Epidemic. The Guardian, London.

https://www.theguardian.com/science/the-h-word/2016/jan/29/rubella-zika-pregna ncy-disability-abortion-epidemic

[21] Associação Jurídico-Espírita do Brasil (2016) Associação espírita é contra aborto em casos de microcefalia. Diário de Pernambuco, Pernambuco.

http://www.diariodepernambuco.com.br/app/noticia/economia/2016/02/21/interna s economia,628226/associacao-espirita-e-contra-aborto-em-casos-de-microcefalia.s $\underline{\mathrm{html}}$

[22] Cancian, N. (2016) Avança de casos de microcefalia 'não justifica defender aborto', diz CNBB. Cotidiano-Folha de São Paulo, São Paulo.

http://www1.folha.uol.com.br/paywall/adblock.shtml?http://www1.folha.uol.com.br /cotidiano/2016/02/1736949-avanco-de-casos-de-microcefalia-nao-justifica-defende r-aborto-diz-cnbb.shtml

[23] Casey, N. (2016) Zika Virus in Colombia Presents Complicated Choice about Abortion. The New York Times, New York.

http://www.nytimes.com/2016/02/16/world/americas/zika-virus-in-colombia-prese nts-complicated-choice-about-abortion.html

[24] Collucci, C. (2016) Alta de microcefalia reacende debate sobre o aborto legal. Cotidiano-Folha de São Paulo, São Paulo.

http://www1.folha.uol.com.br/cotidiano/2016/01/1727899-alta-de-microcefalia-reac ende-debate-sobre-aborto-legal.shtml

[25] Collucci, C. (2016) Pesadelo para as gestantes, vírus da Zika levanta dúvidas, entenda os riscos. Cotidiano, Folha de São Paulo, São Paulo.

http://www1.folha.uol.com.br/saopaulo/2016/05/1766057-pesadelo-para-as-gestante s-virus-da-zika-levanta-duvidas-entenda-os-riscos.shtml

[26] Felix, P., Castro, F. and Formenti, L. (2016) EUA confirmam vínculo entre infecção por zika e microcefalia. Saúde-Estadão, São Paulo.

http://saude.estadao.com.br/noticias/geral,estados-unidos-confirmam-vinculo-entr e-zika-e-microcefalia, 1855809

[27] Ferraz, L. (2016) Maioria dos brasileiros desaprova aborto mesmo com microcefalia. Cotidiano-Folha de São Paulo, São Paulo.

http://www1.folha.uol.com.br/cotidiano/2016/02/1744476-maioria-dos-brasileirosdesaprova-aborto-mesmo-com-microcefalia.shtml

[28] Ferreira, J. (2016) No Acre, ministro defende opção de aborto para fetos com microcefalia. Diário do Nordeste, Fortaleza.

http://diariodonordeste.verdesmares.com.br/cadernos/nacional/online/no-acre-min 
istro-defende-opcao-de-aborto-para-fetos-com-microcefalia-1.1491777

[29] Formenti, L. (2016) Bebê com microcefalia vai ter prioridade em fila de benefício. Saúde-Estadão, São Paulo.

http://saude.estadao.com.br/noticias/geral,crianca-com-microcefalia-tera-prioridad e-em-fila-de-beneficio, 10000049401

[30] Formenti, L. (2016) Ministério lança plano para apressar teste de microcefalia. Saúde-Estadão, São Paulo.

http://saude.estadao.com.br/noticias/geral,ministerio-da-saude-lanca-plano-para-ap ressar-teste-de-microcefalia, 10000021246

[31] Formenti, L. (2016) Maioria das mães de bebês com microcefalia teve erupções cutâneas no início da gravidez. Saúde-Estadão, São Paulo.

http://saude.estadao.com.br/noticias/geral,maioria-das-maes-com-bebes-com-micr ocefalia-teve-erupcoes-cutaneas-no-inicio-da-gravidez, 10000024920

[32] Garcia, A.G. (2016) Sobre bebês golfinhos e bebês humanos. O Povo on line, Fortaleza-CE.

http://www.opovo.com.br/app/jornaldoleitor/noticiassecundarias/artigos/2016/02/2 9/noticiajornaldoleitorartigos,3581334/sobre-bebes-golfinhos-e-bebes-humanos.sht $\underline{\mathrm{ml}}$

[33] Garcia, L. (2016) O vírus Zika e o aborto. O Estado, Pernambuco. http://www.oestadoce.com.br/opiniao/o-virus-zika-e-o-aborto

[34] Garrafa, V. (2016) Especialistas e religiosos debatem aborto em casos de microcefalia. Diário de Pernambuco, Pernambuco.

http://www.diariodepernambuco.com.br/app/noticia/brasil/2016/02/15/interna bra $\underline{\text { sil,626966/especialistas-e-religiosos-debatem-aborto-em-casos-de-microcefalia.sht }}$ $\underline{\mathrm{ml}}$

[35] Girard, F. (2016) Vírus Zika: El Zika y los derechos reproductivos. El País, Madrid. http://elpais.com/elpais/2016/03/15/planeta futuro/1458059218 007104.html

[36] Goldie, J. (2016) Zika Virus Emergency. The Guardian, London. http://www.who.int/emergencies/zika-virus/response/en/

[37] Gollp, T.R. (2016) Leitor diz que jornal é conservador sobre aborto, Folha responde. Painel do Leitor-Folha de São Paulo, São Paulo.

http://m.folha.uol.com.br/paineldoleitor/2016/03/1751931-leitor-diz-que-jornal-e-c onservador-sobre-aborto-folha-responde.shtml

[38] Lee, P.Y. (2016) The Three-Letter Word Missing from the Zika Warnings-Men. The Guardian, London.

http://www.theguardian.com/global-development-professionals-network/2016/feb/ 17/three-letter-word-missing-zika-warnings-men

[39] McNeil Jr., D.G., Romero, S. and Tavernise, S. (2016) How a Medical Mystery in Brazil Led Doctors to Zika. The New York Times, New York.

http://www.nytimes.com/2016/02/07/health/zika-virus-brazil-how-it-spread-explai ned.html

[40] Nunes, K. (2016) Igreja lança canal para ajudar famílias de bebês com microcefalia em PE. Cotidiano-Folha de São Paulo, São Paulo.

http://www1.folha.uol.com.br/cotidiano/2016/03/1749338-igreja-lanca-canal-para-a judar-familias-de-bebes-com-microcefalia-em-pe.shtml

[41] Nunes, K. (2016) Mãe não merece feto sem vida, diz juiz sobre o aborto em caso de microcefalia. Cotidiano-Folha de São Paulo, São Paulo. http://www1.folha.uol.com.br/cotidiano/2016/01/1735564-mae-nao-merece-feto-se m-vida-diz-juiz-sobre-aborto-em-caso-de-microcefalia.shtml

[42] Oliveira, A. (2016) Los casos de microcefalia reabren el debate sobre el aborto en 
Brasil. El País, Madrid.

http://internacional.elpais.com/internacional/2016/01/29/actualidad/1454103307 9 84282.html

[43] Queiroz, T. and Escobar, H. (2016) No front da microcefalia, cientistas encontram uma "sopa de vírus". Saúde-Estadão, São Paulo.

http://saude.estadao.com.br/noticias/geral,no-front-da-epidemia--cientistas-encont ram-uma-sopa-de-virus, 10000018444

[44] Resk, F. (2016) Homens abandonam mães de bebês com microcefalia em PE. Saúde-Estadão, São Paulo.

http://saude.estadao.com.br/noticias/geral,homens-abandonam-maes-de-bebes-co $\underline{\text { m-microcefalia-em-pe, } 10000014877}$

[45] Reuters (2016) Colombia reports more than 2,100 pregnant women have Zika virus. The New York Times, New York, Americas.

http://www.nytimes.com/2016/01/31/world/americas/colombia-reports-more-than2100-pregnant-women-have-zika-virus.html

[46] Ribeiro, B. (2016) Direitos humanos e microcefalia: um desafio brasileiro. SaúdeEstadão, São Paulo.

http://vida-estilo.estadao.com.br/blogs/era-uma-vez/microcefalia-direitos-humanos/

[47] Sahuqullo, M.R. (2016) El temor al zika amenaza com disparar el aborto clandestino em América. El País, Madrid.

http://internacional.elpais.com/internacional/2016/02/02/actualidad/1454430775 8 75881.html

[48] Salomão, A. (2016) Um ano após $1^{\circ}$ caso oficial de microcefalia faz bebê tomar Rivotril. Saúde-Estadão, São Paulo.

http://saude.estadao.com.br/noticias/geral,um-ano-apos-1-caso-oficial-de-zika--mic rocefalia-faz-bebe-tomar-ate-rivotril, 10000026444

[49] Senra, R. (2016) “Aborto já é livre no Brasil; proibir é punir que não tem dinheiro”, diz Drauzio Varella. Cotidiano. Folha de São Paulo, São Paulo.

http://www.bbc.com/portuguese/noticias/2016/02/160201 drauzio aborto rs

[50] Senra, R. (2016) Grupo de prepara ação no STF por aborto em casos de microcefalia. Cotidiano. Folha de São Paulo, São Paulo.

http://www1.folha.uol.com.br/paywall/adblock.shtml?http://m.folha.uol.com.br/coti diano/2016/01/1734795-grupo-prepara-acao-no-stf-por-aborto-em-casos-de-micro cefalia.shtml

[51] Sun, L.H. (2016) Ultrasounds Missed Her Zika Infection-Until One Showed Serious Harm to Her Fetus. The Washington Post, Washington.

https://www.washingtonpost.com/news/to-your-health/wp/2016/03/30/why-ultraso unds-may-give-mothers-with-zika-a-false-sense-of-security/

[52] Sun, L.H. and Dennis, B. (2016) Zika Has Pregnant Women in the US Worried, and Doctors Have Few Answers. The Washington Post, Washington.

https://www.washingtonpost.com/national/health-science/zika-has-pregnant-wome n-in-the-us-worried-and-doctors-have-few-answers/2016/03/07/4c370424-e000-11e 5-8d98-4b3d9215ade1 story.html

[53] Valenti, J. (2016) If Women with Zika Risk Shouldn't Get Pregnant, They Need Abortion Access. The Guardian, London.

http://www.theguardian.com/commentisfree/2016/feb/03/if-women-with-zika-riskshouldnt-get-pregnant-they-need-abortion-access

[54] Watts, J. (2016) Brazil's Sprawling Favelas Bear the Brunt of the Zika Epidemic. The Guardian, London.

https://www.theguardian.com/world/2016/feb/07/brazil-rich-zika-virus-poor 